\title{
Root taxa identification in plant mixtures - current techniques and future challenges
}

\author{
Boris Rewald • Catharina Meinen • \\ Michael Trockenbrodt • Jhonathan E. Ephrath • \\ Shimon Rachmilevitch
}

Received: 13 October 2011 /Accepted: 1 February 2012 / Published online: 16 March 2012

(C) The Author(s) 2012. This article is published with open access at Springerlink.com

\begin{abstract}
Background Studying root biomass, root system distribution and belowground interactions is essential for understanding the composition of plant communities, the impact of global change, and terrestrial biogeochemistry. Most soil samples and minirhizotron pictures hold roots of more than one species or plant individual. The identification of taxa by their roots would allow species-specific questions to be posed; information about root affiliation to plant individuals could be used to determine intra-specific competition. Scope Researchers need to be able to discern plant taxa by roots as well as to quantify abundances in mixed root samples. However, roots show less distinctive
\end{abstract}

Responsible Editor: Alexia Stokes.

B. Rewald $(\bowtie) \cdot$ J. E. Ephrath $\cdot$ S. Rachmilevitch

French Associates Institute for Agriculture and

Biotechnology of Drylands, Blaustein Institutes for Desert

Research, Ben-Gurion University of the Negev,

Campus Sede Boker, Midreshet Ben Gurion,

Beersheba 84990, Israel

e-mail: rewald@rootecology.de

C. Meinen

Department of Crop Sciences, Division of Agronomy, Georg-August-University Göttingen,

Göttingen, Germany

M. Trockenbrodt

Faculty of Forestry, National University of Laos,

Vientiane, Lao PDR features that permit identification than aboveground organs. This review discusses the primary use of available methods, outlining applications, shortcomings and future developments.

Conclusion Methods are either non-destructive, e.g. visual examination of root morphological criteria in situ, or require excavated and excised root samples. Among the destructive methods are anatomical keys, chemotaxonomic approaches and molecular markers. While some methods allow for discerning the root systems of individual plants, others can distinguish roots on the functional group or plant taxa level; methods such as IR spectroscopy and qPCR allow for quantifying the root biomass proportion of species without manual sorting.

Keywords Anatomy and morphology .

Chemotaxonomy · IR Spectroscopy · Molecular markers $\cdot$ Root biomass $\cdot$ Root taxa determination

\section{Introduction}

The location and activity of plant roots play important ecological roles, affecting processes such as competition for water and nutrients, direct plant-plant interactions, dynamics of mycorrhizal fungi and rhizosphere bacteria, and biogeochemistry of soils (de Kroon et al. 2003; Reynolds et al. 2003; Schenk 2006) and may therefore strongly influence ecosystem responses to global change. 
The lack of knowledge on rhizosphere processesas compared to aboveground organs-is partially caused by the inaccessibility of root systems, "the hidden half" of plants (Eshel and Beeckman 2012). Standard methods for studying the abundance, distribution and dynamics of root systems are either to collect (a series of) soil samples or to determine root growth and distribution via picture analyses (e.g., via minirhizotron systems; Rewald and Ephrath 2012). Because spatially segregated root systems are foremost limited to resource-poor environments such as arid and semi-arid areas, roots of more than one plant individual are commonly found in close proximity (Schenk et al. 1999; Rewald and Leuschner 2009; Jones et al. 2011).

Plant taxa can be commonly identified from aboveground criteria, such as flower morphology and, within local communities, usually from leaf shapes; however, roots show less distinctive features that permit identification. While individual roots are sometimes followed back to the stem for identification (Murphy et al. 2009) or whole root systems or plots are excavated by digging (Brisson and Reynolds 1994), most studies addressing rooting patterns or rhizosphere processes are hampered by the lack of broadly applicable methods for discerning plant taxa by their underground parts. Sound abilities to identify species-specific root distributions in time and space would strongly facilitate research in belowground community ecology, including studies on invasive plants, mixed forests, and agricultural systems (e.g., Lopez-Zamora et al. 2004; Rewald and Leuschner 2009). Spatial presence/absence scores, gained by belowground taxa identification, are only part of the information needed. Because root system functions are strongly related to (fine) root densities (Barber 1995), the belowground proportions of species have to be quantified. The quantitative analysis of species' root distribution will improve our understanding of plant carbon allocation and competition in general, and, in addition, has practical implications for irrigation and fertilizer placement in mixed cropping systems. Affiliating root systems to plant individuals is even more complex than taxa differentiation; however, data about root system overlapping in mono-specific agricultural systems and tree plantations are needed to quantify intra-specific competition.

To overcome technological limitations in the relatively young scientific discipline of "root research", several methods-ranging from anatomical and morphological keys to labelling approaches, from infrared absorbance spectra and other chemotaxonomic methods to molecular markers-have been developed. The techniques to identify plant individuals, functional groups or taxa by their underground parts and/or to determine the root proportion of species are summarized in this review to help facilitate their use in future studies.

\section{Anatomical and morphological criteria}

Tree species are routinely identified by using the anatomical characteristics of stem wood. Identifying plant species based on their root anatomy imposes challenges because knowledge of root anatomy is comparatively limited, and important anatomical characteristics can differ between stem and root. For example, wood of Ulmus glabra is ring-porous in the stem, semi-ringporous in roots that are in close proximity to the stem, and diffuse-porous in more distal roots (Fig. 1; Trockenbrodt et al. 2001). Thus, root identification requires specific anatomical keys; however, studies on the comparative anatomy of (woody) roots are relatively rare (e.g., Riedel 1937; Prakash 1972). In 1987, Cutler et al. published a root anatomy key for 280 tree and shrub species from Northern and Central Europe which has become the standard reference for woody root anatomy. To date, a similarly comprehensive anatomical key for herbaceous roots is missing. However, based on their study of the root anatomy of trees, shrubs and herbaceous plants from an Acer saccharum forest, Brundrett and Kendrick (1988) observed that "there was no difficulty in determining the identity of roots [by unique combinations of anatomical features]".

Commonly used characteristics for anatomical root keys are based on xylem traits (e.g., conduit types, xylem vessel distribution, type of perforation plates, pit types, tyloses), parenchyma and sclerenchyma anatomy (e.g., septated fibres, type and position of axial parenchyma, numbers of cells in wood rays), and the appearance and abundance of specific cell contents (e.g., crystalline silicic acid, calcium oxalate; Cutler et al. 1987; Trockenbrodt et al. 2001). For example, anatomical characteristics relevant for the identification of Populus tremula are the presence of secondary phloem fibres and sclereids, and the wedgeshaped dilatation of phloem rays in root bark (Fig. 2a). 

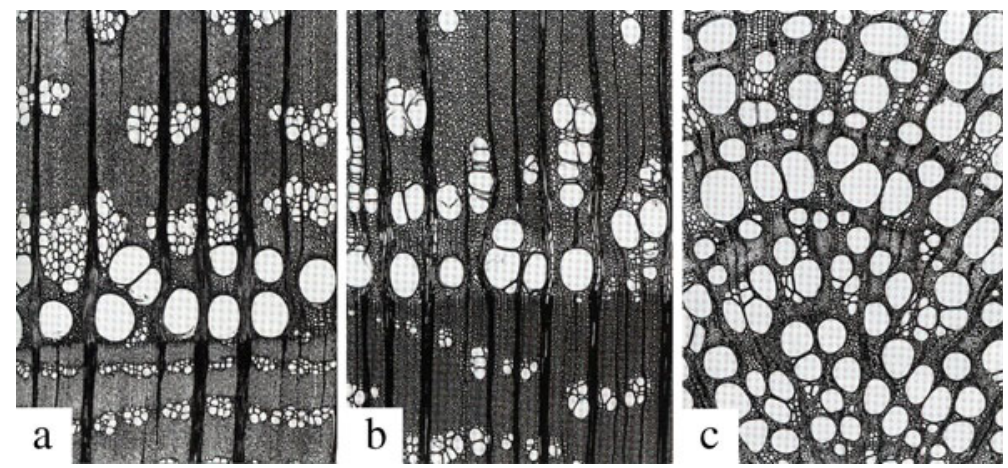

Fig. 1 Anatomical differences between stem and root wood make specific root identification keys necessary. In Ulmus glabra, the xylem vessel distribution changes from ring-porous to diffuseporous. a ring-porous stem; b semi-ring-porous root at $0.8 \mathrm{~m}$

In contrast, sclereid formation is pronounced, but no secondary phloem fibres are formed in Betula pendula root bark (Fig. 2b). While seminal roots of grasses, fibrous roots of herbs and ephemeral fine roots of woody species are more difficult to identify because they show no or minor secondary growth and, thus, less pronounced tissue differentiation than woody roots, root anatomy has been found to be a useful tool for species identification in a range of non-woody species (e.g.,

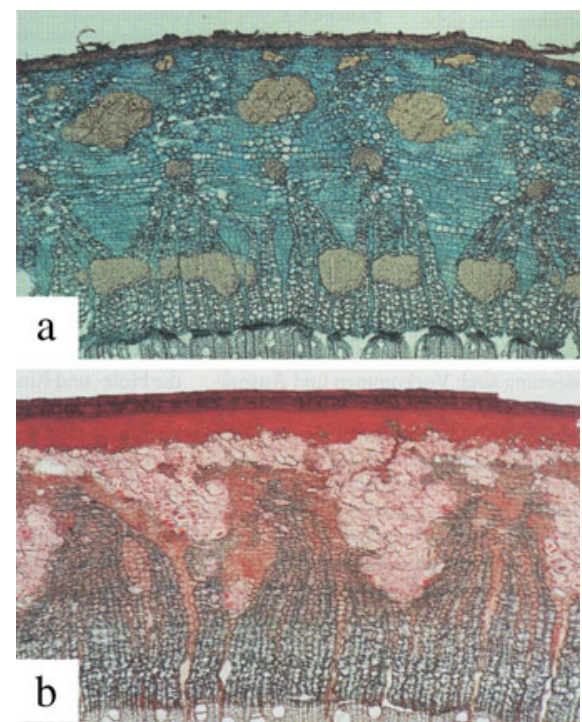

Fig. 2 The anatomical characteristics of young root barks relevant for species identification. Populus tremula $\mathbf{a}$ - formation of secondary phloem fibres and sclereids (yellow), wedge-shaped dilatation of phloem rays (blue); Betula pendula $\mathbf{b}$ - pronounced sclereid formation (whitish-pink), no secondary phloem fibres formed (Trockenbrodt et al. 2001; images reproduced with friendly permission by Patzer Verlag, Berlin) distance to stem; c diffuse-porous root at $7.60 \mathrm{~m}$ distance to stem (Trockenbrodt et al. 2001; images reproduced with friendly permission by Patzer Verlag, Berlin)

Wang et al. 2003, abstract; Basconsuelo et al. 2011). For example, Brundrett and Kendrick (1988) found the structure of the exodermis and epidermis as well as large intercellular spaces to be sufficient characteristics for the identification of small diameter roots $(0.1-2 \mathrm{~mm})$ of herbaceous plants as well as of shrubs and trees in a diverse forest ecosystem.

Due to the destructive nature and the time consuming preparation of cross sections (embedding, staining, etc.), anatomical keys are foremost suitable to determine the taxa of a limited number of excised root segments (but see Brundrett and Kendrick 1988). Ideally, anatomical characteristics used for root species differentiation must be stable under different environments and during ontogeny and are mirrored in the aboveground anatomy for easy taxa affiliation. However, because anatomical root traits can change significantly between environments and within a root system (e.g., Huang and Fry 1998; Rewald et al. 2011), a comparison of cross sections with known root samples from the vicinity and establishment of local keys is required.

\section{Root morphology}

A less time consuming technique, allowing for manual sorting of larger root biomass samples, uses general morphological root traits ("gross morphology") to determine the taxa. Because larger root fragments usually hold more referable criteria than small segments, excessive fragmentation of roots (e.g. by using overly small augers or an abrasive rinsing procedure) needs to be avoided. Finér et al. (1997) identified tree species by comparing key criteria such as root colour, odour, 
resilience (to breakage), type of mycorrhiza, existence of root hairs or resin, and/or woody structure. Meinen (2008) compiled a root identification key for ten deciduous Central European tree species based on colour and gross morphological criteria. The core of this identification technique is the examination of the root surface structure under a dissecting microscope (4-40×), taking the exodermal cell structure and peridermis characteristics (e.g., furrows or dead periderm layers) into special consideration. For example, the rhizodermis of Larix decidua and Prunus avium fine roots $(\leq 2 \mathrm{~mm}$ in diameter) can be reliably used for taxa differentiation (Fig. 3). The roots of Larix decidua are dark brown to reddish, and the surface features thin longitudinal furrows; in contrast, Prunus avium roots are dark brown to beige with rectangular-shaped cells visible in the beigecoloured areas. Furthermore, the gross morphology of root branches, including the root diameter, branching pattern, root tip density and the morphotype of mycorrhizal root tips, is known to differ between species (Agerer 1988; Yanai et al. 2008; Leva et al. 2009;
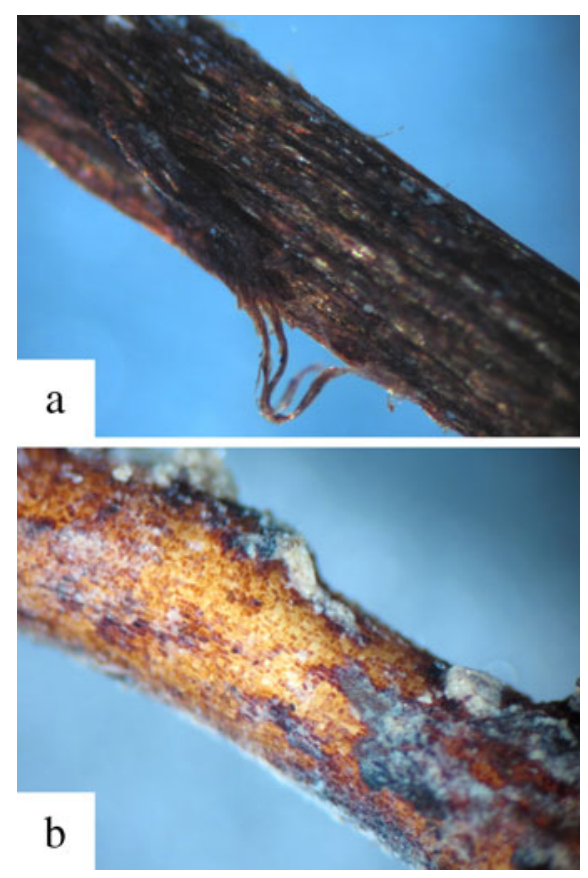

Fig. 3 Larix decidua a and Prunus avium b fine roots, illustrating how the differences among root surface structures can be used for the identification of fine root tree taxa. The fine roots of Larix decidua have a dark-brown to reddish colour and a surface featuring thin longitudinal furrows and a rather filamentary structure. In contrast, Prunus avium fine roots are pied-coloured (i.e. dark reddish-brown to beige) with cell shapes clearly visible in beigecoloured areas (C. Meinen and B. Rewald, unpublished results)
Meinen et al. 2009a). However, although gross morphology-based criteria have been widely used on diverse root mixtures-for example, Meinen et al. (2009b) discerned up to eight tree species and herbaceous roots in a deciduous old-growth forest in Thuringia, Germany-species-specific criteria have yet to be documented in a comprehensive key. An example for a gross morphological key allowing the discernment of Fagus sylvatica and Quercus petraea fine roots can be found in Table 1 (Hölscher et al. 2002, modified).

Gross morphological criteria cannot only be used to distinguish the roots of woody species. Wardle and Peltzer (2003) used general appearance and colour criteria to distinguish Lolium perenne roots from those of dicotyledonous species, "enabling separation of roots into those of component species with a reasonable level of accuracy". Roots of Triticum spp., Zea mays, and Vicia faba were distinguished by colour, texture and rooting pattern by $\mathrm{Li}$ et al. (2006); for example, the roots of Triticum spp. $\left(\mathrm{C}_{3}\right.$ plant) were described as yellowish and hairy as compared with those of Zea mays ( $\mathrm{C}_{4}$ plant), which had smooth surfaces and were of a white colour. Most previous studies comparing root biomass and distribution of non-woody plants used grass/herb or $\mathrm{C}_{3}$ grass $/ \mathrm{C}_{4}$ grass mixtures, possibly leveraging the larger differences in root morphology between more distantly related plant species. However, Vandenkoornhuyse et al. (2003) "identified, [and] separated" roots of Agrostis capillaris, Festuca rubra, and Poa pratensis from seminatural grassland by morphological criteria (see Ridgway et al. 2003); sorting was confirmed by $\operatorname{Tr} n \mathrm{~L}$ intron amplification (see below). Leva et al. (2009) used root colour, hair abundance, diameter, branching pattern and tensile strength to distinguish roots of eight grasses from the Patagonian steppe. Thus, morphological keys can be reliably used to discern even seminal roots in diverse swards; however, many experimental set-ups are limited to a species number of two (e.g., Huber-Sannwald et al. 1998), possibly allowing for more unambiguous discrimination of roots and reducing the time required for training.

The use of colour as a distinction criterion was found to be a valuable method to study belowground interactions in natural habitats and mixed cropping systems (e.g., Tosti and Thorup-Kristensen 2010); however, root colour might be subject to change under different environmental conditions, requiring caution 
Table 1 Gross morphological criteria for distinguishing fine roots of Fagus sylvatica and Quercus petraea trees from habitats in Northern and Central Germany (after Hölscher et al. 2002, modified)

\begin{tabular}{lll}
\hline Criteria & Fagus sylvatica & Quercus petraea \\
\hline Colour & Reddish brown to orange brown & Light brown to beige (rarely yellow) \\
Root surface structure & $\begin{array}{c}\text { Rough surface with longitudinal } \\
\text { furrows; dead, flaky periderm }\end{array}$ & $\begin{array}{c}\text { First order roots with lateral furrows, partly with visible cell } \\
\text { structure; roots partly coated with shiny, transparent, dead } \\
\text { periderm layers }\end{array}$ \\
Branching structure & $\begin{array}{c}\text { Evenly ramified with numerous } \\
\text { clustered root tips }\end{array}$ & $\begin{array}{l}\text { Long, winding and less ramified first order branches. } \\
\text { Root slightly thickened at branching points }\end{array}$ \\
Mycorrhizal status & Ectomycorrhizal fungi & Ectomycorrhizal fungi
\end{tabular}

in using colour as a sole criterion. The use of colour tables and the three variables of hue, brightness and saturation have been suggested to make colour estimation less arbitrary (Leva et al. 2009).

A main drawback of gross morphological keys is the plasticity of root morphology under changing environments and with mycorrhization status (e.g., Taylor et al. 2008); thus, keys often need local adjustment. Furthermore, broad usage of gross morphological keys is limited by the time consuming hand sorting process of root segments and the extensive operator training required, making high throughput root identification and biomass sorting by morphological criteria labour intensive. However, morphological keys are envisioned to continue to be used in future studies because the method compels by its very low set-up costs and the possibilities to discern roots in situ (e.g. for manipulation of competitive neighbourhoods) or to use excised root segments for further analyses (e.g., specific root area, chemical composition, mycorrhization etc.; Rewald and Leuschner 2009).

\section{Staining}

When natural colour differences or morphological parameters are not sufficiently pronounced or rooting of individual plants should be mapped, root staining was suggested (Böhm 1979). In 2003, Holzapfel and Alpert used dyes to relate root segments harvested by soil coring to either one of two Fragaria chiloensis plants. The dyes were fed through cut leaf petioles; the plants had to be sufficiently dry, and all leaves were cut prior to the dye application. Similarly, Murakami et al. (2006) developed a technique to stain the root systems of several herbaceous crop species via injecting a dye solution into the clipped shoot. Using this technique, the root systems of two pot-grown Lycopersicon spp. plants have been clearly identified by using either red or blue dye (Fig. 4). As reported by Holzapfel and Alpert (2003) and Murakami et al. (2006), a highly desiccated soil is necessary prior to staining, in order to induce sufficient downward flux of the dye. The direct staining of root systems is thought to be most useful to distinguish the root systems of neighbouring plants in detail (Cahill et al. 2010); root biomass

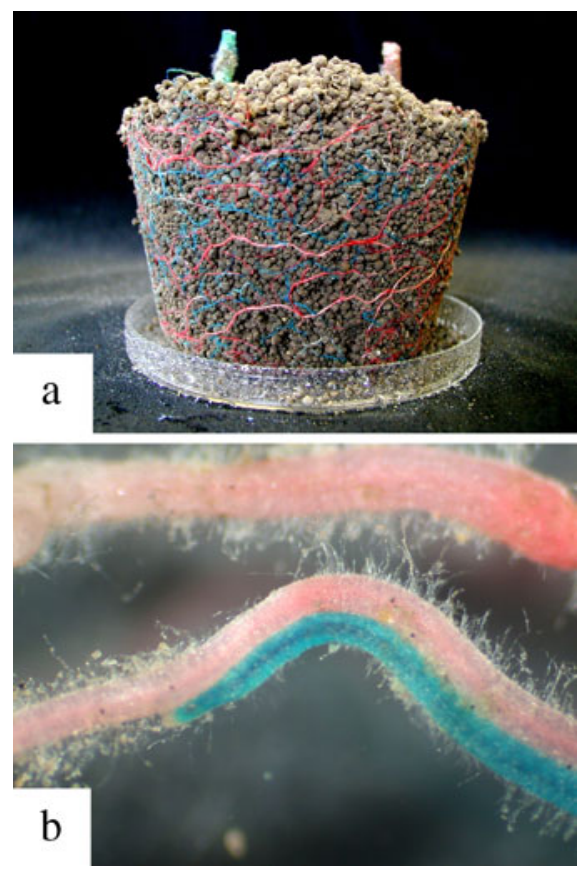

Fig. 4 The root systems of two Lycopersicon spp. plants, stained 53 days after sowing with either red or blue dye. a shows the distinguishably stained root systems after pot removal; b provides a close-up view of the stained roots in parallel adhesion (Murakami et al. 2006; images courtesy of T. Murakami, National Agriculture Research Center for Tohoku Region, Fukushima, Japan) 
can be quantified by manual sorting or colourbased image analyses (e.g., WinRhizo Pro, Regent Instruments, Canada). Cahill et al. (2010) reported that $>90 \%$ of Abutilon theophrasti roots, growing under intraspecific competition in pots, could be attributed to a plant individual by either stain colour and/or visible connection to other roots of known ownership. However, the method seems to be limited to small plants growing in dry soil to allow for sufficiently stained root systems.

Donaldson and Robinson (1971) and others applied fluorescent dyes to soils where they were rapidly absorbed and transported to aboveground organs. This technique, similar to isotope tracer applications (see below), could be a valuable tool to determine the affiliation of (partially) excavated roots, as are available in studies using removable root windows or inflatable minirhizotron tubes, to individual plants if applied directly to root segments. However, the potential range of the technique is restricted, i.e. large scale mapping of root system distribution is impossible, and the size of eligible plants might be limited due to dilution effects.

\section{Infrared spectroscopy and fluorescence}

Infrared (IR) spectroscopy is a standard method in labs for quantitative determination and identification of unknown substances; the IR spectrum ranges between the visible and microwave region. Traditionally, the unit wavenumber (i.e. the inverse of the wavelength in $\mathrm{cm}$ ) is used to describe the spectrum. The IR region can be divided into near (wavenumber 12,500-4,000 $\mathrm{cm}^{-1}$ ), mid $\left(4,000-400 \mathrm{~cm}^{-1}\right)$, and far $\left(400-5 \mathrm{~cm}^{-1}\right)$ infrared. The principle of IR spectroscopy is irradiating a sample and recording the spectral patterns; the chemical composition of a sample determines the spectral print as a function of wavenumber (Chalmers and Griffiths 2002; Günzler and Gremlich 2002). Thus, the spectral pattern reveals information about the chemical composition of a sample, e.g. the presence of - $\mathrm{OH},-\mathrm{CH}$, and - $\mathrm{NH}$ bonds. Similarly, fluorescence spectroscopy uses a beam of light, usually ultraviolet (UV) light (wavelength 230$400 \mathrm{~nm}$ ), that excites electrons in certain compounds and causes them to emit light of a lower energy (Sharma and Schulman 1999). The differences in the chemical composition of roots (see also below), detected by absorption or transmission spectroscopy or fluorescence intensity, can be utilized for taxa identification below ground.
Near infrared reflectance spectroscopy

Near infrared reflectance spectroscopy (NIRS) is a rapid and cost-effective tool in constituent analysis and considered a valuable tool for ecological applications (Foley et al. 1998). In agricultural studies, NIRS analysis has been used to determine the aboveground proportion of legumes in legume-grass mixtures (Shenk et al. 1979) and complex forage mixtures (Coleman et al. 1985). For studying roots, NIRS was applied first by Rumbaugh et al. (1988) to predict the root biomass proportion of four grass species in binary mixtures with Medicago sativa. Artificially prepared Medicago-grass root mixtures with grass ratios from 0 to $100 \%$ were recorded by NIRS, and root spectra were correlated to corresponding root proportion $\left(R^{2}=0.92-0.99\right)$. Similar, Roumet et al. (2006) created artificial root mixtures with combinations of two or three species from greenhouses (Festuca arundinacea, Holcus lanatus, Lolium perenne) or from species collected in an old-field (Brachypodium phoenicoides, Bromus erectus, Picris hieracioides). These mixtures were used to calibrate a NIRS model to predict species proportion $(R=0.97-0.99)$. Recently, the prediction of the species ratio in woody fine-root mixtures (Fagus sylvatica, Quercus petraea, Picea abies, Pseudotsuga menziesii - with two, three, or four tree species plus herbal roots) was successfully demonstrated by Lei and Bauhus (2010). Even in samples with low root abundance $(<15 \%)$ of a specific species, NIRS models presented reasonable approximations of the biomass abundance.

\section{Mid-infrared spectroscopy}

Mid-infrared spectroscopy (MIRS) with an attenuated total reflection (ATR) device can penetrate samples to a depth of a few $\mu \mathrm{m}$, compared to NIRS with penetration depths of approximately $27-180 \mu \mathrm{m}$ (Clarke et al. 2002). One advantage of MIRS-ATR, compared with NIRS, is the more structural spectra and display of the "fingerprint region" $\left(1,500-600 \mathrm{~cm}^{-1}\right)$ which is highly characteristic for specific substances and, consequently, beneficial for taxa identification (Skrabal 2009). Today, Fourier transform infrared (FT IR) spectroscopy is commonly used, replacing grating dispersion IR spectrometers. FT IR spectroscopy offers many advantages, such as short measuring times and high signal-to-noise ratios. Methodologically, FT IR 
spectroscopy records an interferogram (result of the reflected wave trains) which is converted by Fourier transformation into an absorption or transmission spectrum (Fig. 5).

Kim et al. (2004) demonstrated that FT IR spectroscopy detects differences in the cell-wall composition of leaves, reflecting the phylogenetic relationship between the tested plants. Zhao et al. (2004) were able to identify wheat varieties using FT IR spectra. Lately, a $100 \%$ correct discrimination of Pisum sativum and Avena sativa roots was achieved by FT MIR-ATR spectroscopy, independent of substrate, competitive environment and root segment position (Naumann et al. 2010). In a recent experiment, Beta vulgaris ssp., Brassica napus, Triticum aestivum, and Zea mays were grown in a greenhouse for 6 weeks (C. Meinen, unpublished). Root segments, taken from the middle section of a rootlet, were dried, and spectra were collected by FT MIR-ATR spectroscopy (Fig. 5). A cluster analysis showed that the four species were separated in four clusters (Fig. 6). The inter-specific differences of the species were higher than the intraspecific heterogeneity; as expected, the differences between monocotyledons and dicotyledons were more pronounced than within one group.

Up to now, IR spectroscopy is commonly used on excavated, excised roots. Only drying and no/minimal grinding is required for most IR spectroscopes without an ATR device and makes the methods well suitable for the analysis of large sample sizes. Because water causes a strong absorbance which can cover the peaks of other components, it was recommended to dry the sample before recording FT IR-ATR spectra (Hsu 1997). However, although fingerprint regions are more distinct with dry and ground roots, FT IR-ATR allows for non-destructive measurements on fresh roots (C. Meinen, unpublished). A non-destructive approach was tested by Nakaji et al. (2008) on hybrid poplar cuttings, using root windows in combination with visible (VIS) and near-infrared (NIR) reflectance images. While Nakaji et al. (2008) used the NIR technique to discriminate soil, leaf mould, and dead and living roots non-destructively, IR spectroscopy techniques have the potential to discriminate taxa in situ. Pierret (2008) suggested that multi-spectral imaging systems-as used by Nakaji et al. (2008)-should be included in future minirhizotron systems to allow for species-specific measurements of root dynamics in plant mixtures. However, the main drawback of IR spectrometry is the exact calibration series needed to determine species ratios. To create artificial root mixtures, designated species should be grown in monocultures to ensure root affiliation to target species. This is laborious and time consuming, especially because the chemical composition of roots can change during ontogeny and under different abiotic and biotic
Fig. 5 Fourier transform mid-infrared spectroscopyattenuated total reflection (FT MIR-ATR) spectra of Beta vulgaris ssp., Brassica napus, Triticum aestivum and Zea mays. The plants were grown in a greenhouse for 6 weeks in a sand-compost mixture; samples were collected at the middle section of a rootlet (mean, $n=9$; C. Meinen, unpublished results)

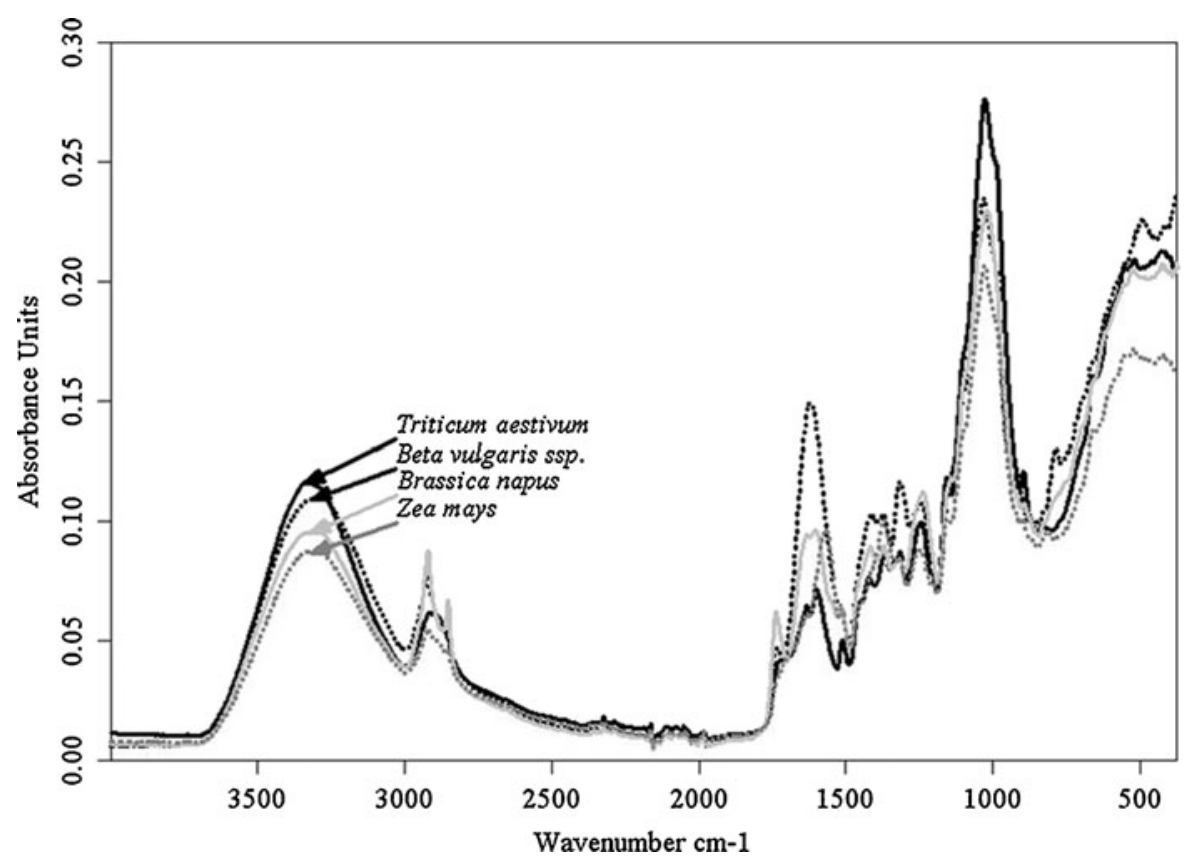




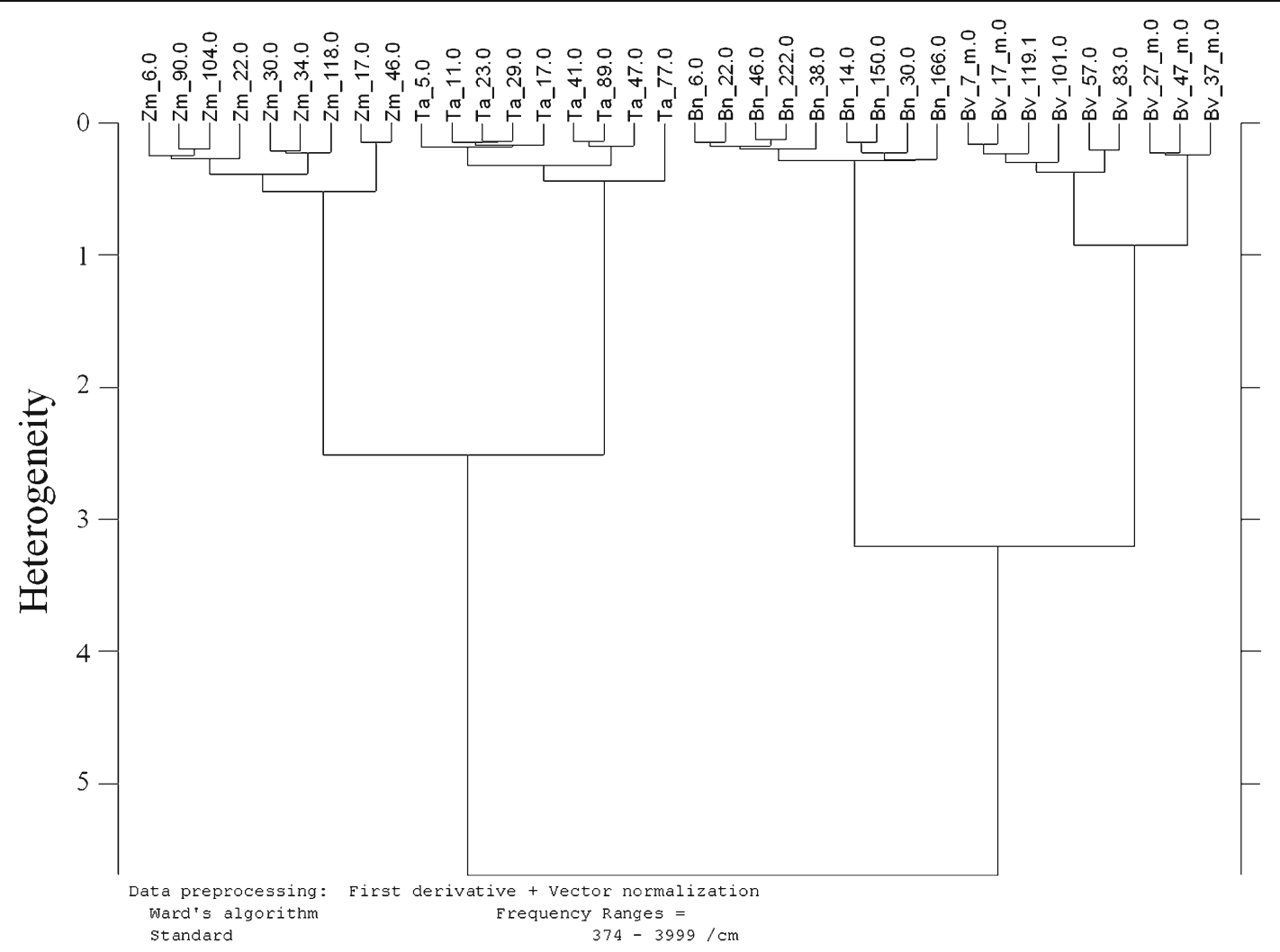

Fig. 6 Cluster analysis of FT MIR-ATR spectra (see Fig. 5) recorded from rootlets of Beta vulgaris ssp. (Bv), Brassica napus (Bn), Triticum aestivum (Ta) and Zea mays ( $\mathrm{Zm})$. The

environments (e.g., by inoculation with rhizobacteria, El Zemrany et al. 2007). Hence, quantitative IR spectroscopy may be primarily applicable to studies where small numbers of well-known species tend to be examined, sufficient amounts of pure root material for calibration can be accessed and environmental gradients during measurements are rather moderate (e.g., agri- or silvicultural ecosystems).

\section{Fluorescence}

Due to its sensitivity, simplicity and selectivity, UVlight induced fluorescence has been broadly used for chemical analyses of autofluorescing molecules (Sharma and Schulman 1999). Goodwin and Kavanagh (1948) tested plant roots to evaluate their fluorescence ability; 135 plant species showed fluorescence when irradiated with long-wave ultraviolet light. However, in situ root observations of Glycine max showed that nutrient absorption and root elongation rates were positively correlated to fluorescence root segments of nine individual plants (i.e. numbers behind species abbreviation) were excised at the middle section of a rootlet (C. Meinen, unpublished results)

intensity (Dyer and Brown 1983) and that fluorescence can be influenced by microbial colonisation (Gamalero et al. 2004). Thus, non-species-specific influences undermine the applicability of UV-lightinduced autofluorescence to root classification. However, more advanced fluorescence spectroscopy approaches (Sharma and Schulman 1999) are envisioned to lead to results as good as those gained through IR spectroscopy techniques.

Avoiding problems with non-species-specific influences on root fluorescence intensity, Faget et al. (2010) used transgenic Zea mays, expressing green fluorescent protein (GFP), in combination with either its corresponding wild-type, Lolium multiflorum or Glycine max. GFP expressing and non-GFP plants can be easily distinguished by the strong, green fluorescence of transgenic roots as compared with minor autofluorescence in wild-type roots (Fig. 7). The identification of fluorescent roots on minirhizotron pictures allows observations of species-specific root distribution, root growth, and root system interaction 


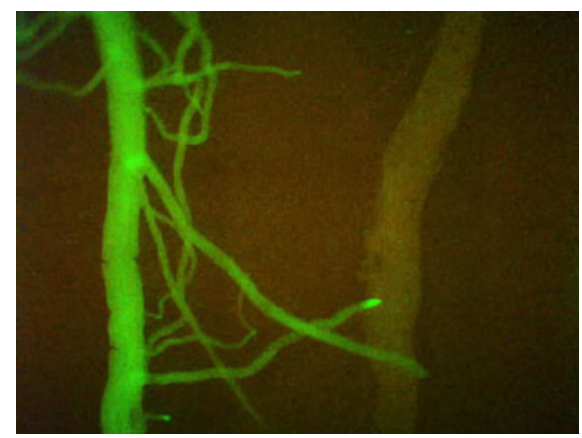

Fig. 7 The roots of a genetically transformed Zea mays genotype expressing green fluorescent protein (GFP); the dark nonfluorescent root on the right side belongs to a non-GFP Zea mays variety (Faget et al. 2009; image courtesy of M. Faget, M. Liedgens, P. Stamp, P. Flutsch and J.M. Herrera, ETH, Zurich, Switzerland)

and interference in situ (Rewald and Ephrath 2012). The ability to mark only certain plant individuals in a monoculture would allow the use of the technique for the determination of intra-specific interactions between plant individuals. While the method is projected to be of interest to a broad range of root researchers, GFP expression is most stable in model plants and the transformation of a larger set of plant species is laborious. Hence, GFP fluorescence may be most applicable in studies where a low number of species tend to be examined, e.g. in an agricultural context.

\section{Chemical and biochemical analyses}

Isotope discrimination and radioisotope labelling

Distinguishing root taxa by natural carbon isotope discrimination relies on the biological principle that $\mathrm{C}_{3}$ species discriminates more effectively than $\mathrm{C}_{4}$ species against the relatively rare isotopic form $\left({ }^{13} \mathrm{C}\right)$ of $\mathrm{CO}_{2}$ (e.g., Farquhar et al. 1989). This results in different ${ }^{13} \mathrm{C}:{ }^{12} \mathrm{C}$ isotope ratios (expressed as $\delta^{13} \mathrm{C}$ ) in the root tissues of $\mathrm{C}_{3}$ and $\mathrm{C}_{4}$ species, with $\mathrm{C}_{3}$ plants having more negative $\delta^{13} \mathrm{C}$ values. Using stable isotope discrimination is particularly useful for estimating the proportion of $\mathrm{C}_{3}$ and $\mathrm{C}_{4}$ species in excised samples of visually indistinguishable, intermingled root systems from intercropping systems or natural plant communities (e.g., Ludlow et al. 1976; Svejcar and Boutton 1985; Wong and Osmond 1991; Gealy and Fischer 2010). For example, Eleki et al. (2005) successfully segregated root systems of Zea mays and Trifolium ambiguum; Zea-Trifolium root mixtures with Zea mays proportions from 1 to $100 \%$ were recorded to correlate $\delta{ }^{13} \mathrm{C}$ values and the corresponding root proportions (Fig. 8). $\mathrm{R}^{2}$ was usually very high between the actual and the predicted root mass ratio, allowing for an accurate determination of root biomass proportions in $\mathrm{C}_{3}-\mathrm{C}_{4}$ mixtures. Aboveground, leaf $\delta^{13} \mathrm{C}$ values were found to differ even between closely related $\mathrm{C}_{3}$ species (e.g., Quercus spp., Williams and Ehleringer 2000). If the same holds true for root $\delta^{13} \mathrm{C}$ values, this could be utilized for root taxa identification in $\mathrm{C}_{3}$ mixtures in the future. However, tissue $\delta^{13} \mathrm{C}$ varies strongly under different environments, especially under different water availability, and responses can differ by species and under competition (Rice et al. 1993; Kloeppel et al. 1998), highlighting the need for costly $\delta^{13} \mathrm{C}$ standard curves for different study years and species.

Differences between legumes and non- $\mathrm{N}$-fixing plants in the ratios of stable nitrogen isotopes ${ }^{15} \mathrm{~N}$ to ${ }^{14} \mathrm{~N}$ have been widely documented (e.g., Shearer et al. 1983). Furthermore, foliar $\delta^{15} \mathrm{~N}$ ratios of herbaceous and woody species are often not related to growth form or phenology, but a strong relationship exists between mycorrhizal status and plant $\delta^{15} \mathrm{~N}$. For example, Schmidt and Stewart (2003) found that Australian woody species with ectomycorrhizal fungi had the lowest foliar $\delta^{15} \mathrm{~N}$, arbuscular species had intermediate $\delta^{15} \mathrm{~N}$ values, and non-mycorrhizal Proteaceae had the highest ${ }^{15} \mathrm{~N}$ proportion; similar differences were observed between AM and non-mycorrhizal herbaceous

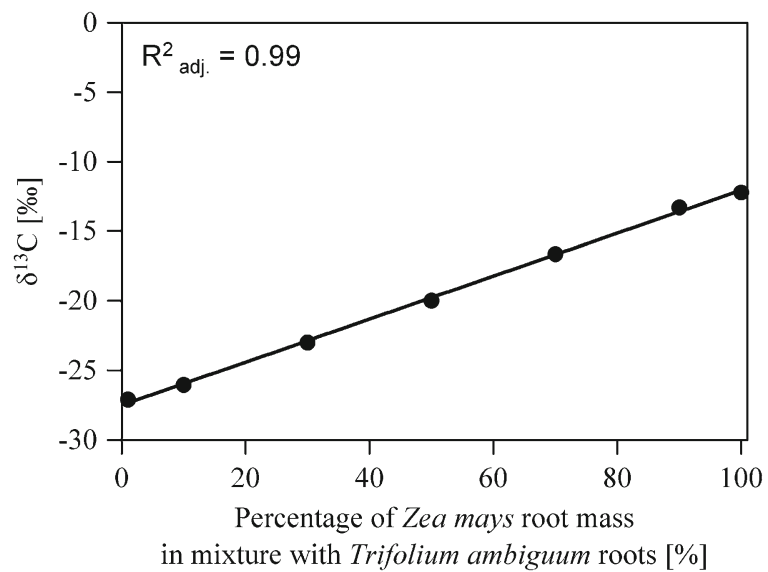

Fig. 8 The relationship between $\delta^{13} \mathrm{C}$ and the proportion of Zea mays roots in mixed samples containing known amounts of excised Zea mays and Trifolium ambiguum roots (after Eleki et al. 2005, modified) 
species. However, these differences, which result from variations in the abundance of ${ }^{15} \mathrm{~N}$ between atmospheric/soil pools of $\mathrm{N}$, and the isotopic fractionation, occurring during $\mathrm{N}$ uptake, have rarely been exploited to distinguish roots. One of the few studies was conducted by Corre-Hellou and Crozat (2005); they successfully used the differences in ${ }^{15} \mathrm{~N}$ abundance and $\mathrm{N}$ concentration between two legume species and Hordeum vulgare to quantify root biomass proportions. Problems can arise if, for example, the legume and the non-fixing plant differ in root distribution, temporal $\mathrm{N}$ uptake patterns, or preferences for soil $\mathrm{N}$-forms. While this approach assumes there is no translocation of $\mathrm{N}$ between plants and that $\delta^{15} \mathrm{~N}$ values are homogeneously distributed within root systems, it is envisioned to facilitate root identification on taxa- or "mycorrhization type"-level in future studies. This holds especially true if combined approaches, using multiple stable isotopes, are used to separate the roots of single species or of functional groups (Polley et al. 1992; Dawson et al. 2000). Polley and colleagues (1992) were able to determine the root biomasses of legumes and non-fixing $\mathrm{C}_{3}$ and $\mathrm{C}_{4}$ plants, in mixed grass-scrubland communities, with differences in the ratios of stable $\mathrm{C}$ and $\mathrm{N}$ isotopes, and $\mathrm{C}$ and $\mathrm{N}$ concentration. For the four species tested, $\mathrm{R}^{2}$ for the actual and estimated root mass was 0.99 , indicating that combined stable isotope signatures provide an expensive but reliable and relatively fast method for estimating root biomass in mixed stands.

Besides using natural variances in isotope abundances, several researchers have used radioactive isotopes to distinguish root species. Litav and Harper (1967) labelled one of two plants grown in mixture with ${ }^{14} \mathrm{C}$ via leaf fumigation. After harvest, excised segments were checked for ${ }^{14} \mathrm{C}$ presence by autoradiography, indicating the parental origin of the individual root. Similarly, Baldwin and Tinker (1972) and Fußeder (1986) used autoradiographic signatures of ${ }^{32} \mathrm{P},{ }^{33} \mathrm{P}$, and ${ }^{35} \mathrm{~S}$. Bookman and Mack (1982) successfully applied a double-labelling approach using $\mathrm{Cs}$ and $\mathrm{Rb}$ to determine the spatial distribution of the root systems of Bromus tectorum and Poa pratensis. The uniform distribution of isotopes in the root system is crucial for all labelling methods and requires, for example, knowledge about the movement of labels through soil, plant metabolism and root activity, including root exudation. The individual labelling of plants has advantages, especially with regard to overcoming the rather small differences in natural isotope ratios and in allowing for intra-specific root distinguishing. However, the clear disadvantages of the radioactive labelling technique include the hazardous potential and the inability to use the method in situ or in large scale studies.

\section{Biochemical markers}

Various products of secondary plant metabolism have been used extensively in botanical chemotaxonomic studies. For example, plant wax alkanes and fatty alcohols have been found to show differences among individual species and have been used to determine species and plant organ composition above ground (Dove et al. 1996; Ali et al. 2005). Similarly, flavonoids have been shown to be useful chemotaxonomic markers in certain plants, e.g. the Leguminosae; however, characteristic leaf flavonoids used for taxa determination are often absent or substituted in roots (Seneviratne and Harborne 1992; Hegnauer and Hegnauer 2001). In a fast and relatively simple approach, Caldwell et al. $(1987,1991)$ circumvented this problem by using the fluorescence intensity of root extracts under UV light to distinguish Artemisia tridentata and grass roots in soil cores (together with root colour criteria, see above). However, chemotaxonomic approaches often require knowledge of root-specific marker molecules which may underlie the infrequent use of this technique for root taxa determination.

In a study on several grass species, Dawson et al. (2000) showed that $n$-alkanes (i.e. with different numbers of $\mathrm{C}$ atoms in the chain) were present in both shoot and root tissues. Using a canonical variance analysis, the roots of all grass species could be separated using concentrations of $\mathrm{C}_{26}, \mathrm{C}_{31}$ and $\mathrm{C}_{33}$-alkanes. Roumet et al. (2006) determined both $n$-alkanes and $n$-alcohol concentrations in roots of five Poaceae and one Asteraceae species (Fig. 9). They found that $n$-alcohols predicted root biomass more accurately than $n$-alkanes with only marginal improvements by joint analysis $(r=0.89-$ $0.99)$. Similarly, $n$-alcohol signatures have been used successfully to quantify the root mass fractions in binary grass mixtures (Soussana et al. 2005). Speciesdependent analysis of either $n$-alkane or $n$-alcohol concentrations shows great potential in quantifying the species composition of grass and herb root mixtures (Dawson et al. 2000; Dove and Bolger 2005) although its accuracy was found to be somewhat lower than the use of NIR spectral analysis (see above; Roumet et al. 


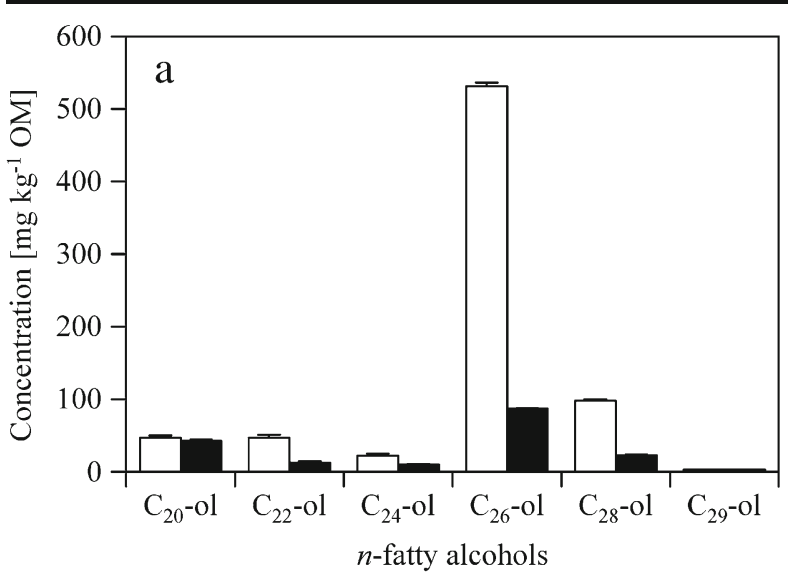

Fig. 9 The concentration of $n$-fatty alcohols $\mathbf{a}$ and $n$-alkanes $\mathbf{b}$ in the roots of container-grown Festuca arundinacea (open bars) and Holcus lanatus (filled bars). The concentration is given relative to

2006). However, a disadvantage of the method, besides requiring the appropriate analytical facilities, is in the large amount of pure root material needed for calibration. According to Roumet and colleagues (2006), the calibration of each species required the preparation of $>40$ artificial mixtures in which the proportion of the species considered varied continuously; the amount of pure reference samples needed per species was approximated as $15 \mathrm{~g}$ d.wt, which is difficult to harvest in situ. As with other methods, problems may arise from changing chemical properties under different environmental conditions (Soussana et al. 2005). However, the application of chemotaxonomic criteria is promising, especially in plant communities with known species composition. Future studies should evaluate if other intrinsic secondary metabolites of roots, such as neutral cumarins (Nordby and Nagy 1981) or anthraquinones (Van Wyk et al. 1995), are similarly useful for reliable root taxa and biomass determination in other genera.

\section{Isozymes}

Isozymes (or isoenzymes) are defined as the different molecular forms in which proteins may exist. Isozymes are a valuable tool for analysing gene variability, allowing for comparative studies of taxa, and are commonly used to identify cultivars of scions and rootstocks (e.g., Walker and Liu 1995). Evidence exists that isozymes may even reflect specific root morphology (Lafitte et al. 2001). While isozymes extracted from root tissue have rarely been used for taxonomical purpose (e.g., Button et al. 1976) and nowadays molecular markers are more

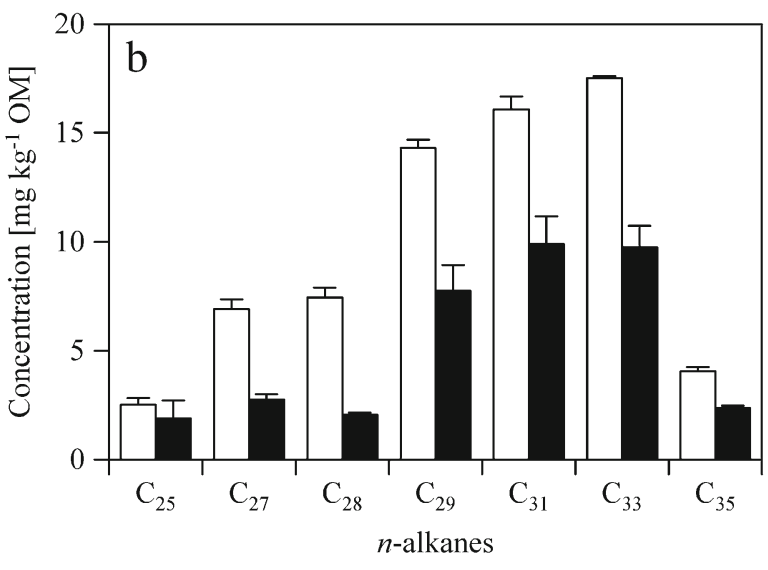

organic matter $(\mathrm{OM})$ content (mean $+\mathrm{SE}, n=3$; after Roumet et al. 2006, modified)

popular (see below), isozymes are still an inexpensive marker system to identify low levels of genetic variation between taxa within one habitat; however, isozymes are subject to changes under different environmental conditions and are inapplicable for the quantification of root systems or the determination of parental plant individuals.

\section{DNA-based techniques}

Molecular methods, based on genomic differences between species, circumvent the problem of changing anatomical, morphological and biochemical properties under different environmental conditions. Following the pioneer work on the molecular identification of woody roots (Jackson et al. 1999), several protocols to identify and quantify the roots of species were developed in the past decade.

Techniques that allow taxa identification of root segments make use of species-specific DNA sequences by 1) sequencing the internal transcribed spacer (ITS) region of ribosomal RNA genes without (Jackson et al. 1999; Linder et al. 2000) or with species-specific primers (McNickle et al. 2008; Mommer et al. 2008), 2) sequencing the large subunit of the ribulose-bisphosphate carboxylase gene $(r b c \mathrm{~L})$ or other marker regions such as intergenic spacers (Kesanakurti et al. 2011; Jones et al. 2011), or 3) analysing several marker regions (most commonly tr $\mathrm{L}$ ) using restriction fragment length polymorphisms (RFLP, Fig. 10; Bobowski et al. 1999; Brunner et al. 2001; Moore and Fields 2005) or 


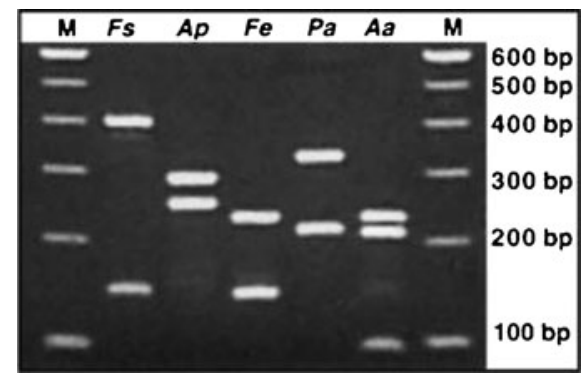

Fig. 10 The agarose gel shows the separation of TaqI restriction fragments of the PCR-amplified plastid trnL-introns of Fagus sylvatica (Fs); Acer pseudoplatanus (Ap); Fraxinus excelsior $(\mathrm{Fe})$; Picea abies $(\mathrm{Pa})$; Abies alba $(\mathrm{Aa})$ by electrophoresis (M, DNA marker bands; Brunner et al. 2001; image reproduced with friendly permission of John Wiley \& Sons Publisher, New York)

fluorescent fragment length polymorphisms (FFLP, Ridgway et al. 2003; Frank et al. 2010; Taggart et al. 2011). Some studies combined sequencing and restriction digest approaches (e.g., Ridgway et al. 2003).

For all methods, DNA extraction and amplification are crucial factors and often require modified extraction protocols, intensive purification approaches and/ or modified primer or polymerase volumes compared to work on aboveground tissues, especially if polyphenolic and secondary compounds are present (e.g., Brunner et al. 2001; Kesanakurti et al. 2011). Moreover, DNA extraction protocols have been optimized on the roots of dicotyledons but possibly need to be adjusted to monocotyledon species, following observations that they were less frequently detected in mixed species samples (Taggart et al. 2011). Alternatively, primers have to be adapted to increase the successful amplification of monocot DNA in mixed samples.

Beside this, the various qualitative approaches have different strengths and limitations. For example, ITS sequences may vary within species or individuals (Moore and Fields 2005 and references within), requiring a reference database of locally occurring species. Intraspecific polymorphisms and hybridization can make species-level identification using ITS sequencing similarities impossible (Linder et al. 2000); they might also affect RFLP analyses, although RFLP seems less vulnerable than ITS-based techniques (Brunner et al. 2001). The FFLP approach by Taggart et al. (2011) and others tried to circumvent these problems by using standardized sequence-based markers from the plastid genome, whose homology is explicit-a process known as plant "DNA barcoding” (CBOL Plant Working Group 2009).
Applying their approach to root samples of a highly diverse, fescue grassland community, Taggart et al. (2011) were able to identify $80 \%$ of 95 species present ( $97 \%$ of 77 genera). Because the homology of fragment length-based markers was suggested to be harder to determine, especially for distantly related taxa, Kesanakurti et al. (2011) sequenced the single-loci barcode $r c b \mathrm{~L}$ using standard primers on randomly chosen root fragments from an old-field. Interestingly, their approach discovered 19 out of 39 species detected aboveground and reported that ten additional taxa detected below ground were not observed in the aboveground plots. These results emphasise that using the global species pool as a reference risks higher rates of false positives; however, if unknown root samples are compared only to species found above ground, as suggested by Taggart and co-workers (2011), cryptic species will be missed. Hence, the selection of the reference sequence database highly influences the recovered species below ground. The accuracy of barcoding approaches can be increased, and the risk of false positives decreased, by using multiple barcode regions simultaneously (Kress et al. 2009). Recently, Jones et al. (2011) applied a multiloci barcoding approach on single root segments of a hyper-diverse lowland tropical moist forest. In their study, Jones et al. (2011) recovered 33 species (14\% of woody species detected aboveground) from 12 soil cores, with an average of 4.6 species per soil core, by sequencing $t r n \mathrm{H}-p s b a$ and $r c b \mathrm{~L} a$ regions. However, while analysing multi-loci barcodes is highly accurate, it is also of limited use if highly diverse ecosystems are studied and species information is not yet available in public gene databases or local DNA sequence reference libraries as available on Barro Colorado Island (Jones et al. 2011). However, with commercial sequencing facilities becoming broadly available, throughput is increased and costs are reduced constantly (Hudson 2008). Thus, when global DNA barcode libraries are available for a wide range of plant species, barcoding techniques will become a widely applied method for high throughput root identification, especially applicable on studies on root system distribution.

Most techniques used to date analyse root segments separately by manual, randomized subsampling from root mixtures; this not only requires an additional sorting step and means analysing huge sample numbers but also increases the risk to lose species present in low root densities. Moore and Field (2005) were the first to successfully developed a technique for identifying 
species presence or absence in multi-species root samples; digested ITS regions were shorter in Poaceae than in Asteraceae, so size differences were sufficient to distinguish these taxonomic groups in mixtures. Applied to modern barcoding approaches, for example, this means that root identification by Sanger sequencing of individual root fragments needs to be replaced by parallel, "next-generation" sequencing (Hudson 2008) of mixed root samples in the future to exploit its full potential.

Using qualitative presence-absence scores of species to estimate relative species proportions in mixed root samples by DNA-based approaches would require the analysis of a very large number of single root segments. Thus, Mommer et al. (2008) developed a real-time PCR method to quantify the relative contribution of two grasses and two forbs to root biomass in rinsed, mixed samples. Mommer and colleagues designed speciesspecific primers, obtained from intersimple sequence repeat (ISSR) analyses, to develop a quantitative RTPCR protocol; the relationship between the percentage of fresh weight per species present and the estimated percentage using their qPCR method was strong and reproducible ( $R=0.92-0.95$; Fig. 11$)$. However, individual estimates had a relatively high confidence limit (approx. 10-15\% deviation from the mean) for a given

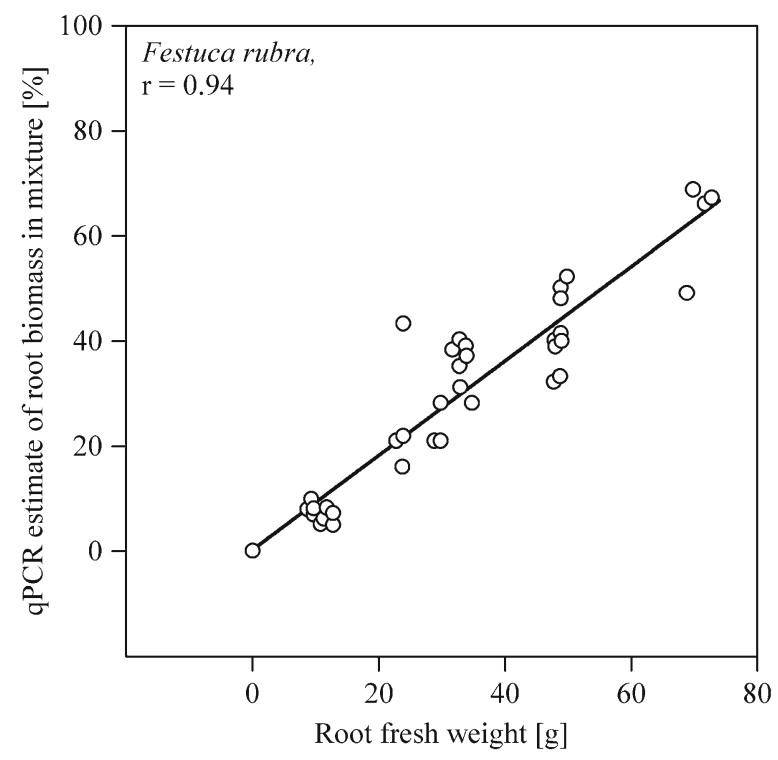

Fig. 11 Estimated percentage presence of Festuca rubra roots in mixed samples by qPCR vs. actual percentage presence (fresh weight). Festuca roots are in mixtures with Anthoxanthum odoratum, Leucanthemum vulgare and Plantago lanceolata roots (after Mommer et al. 2008, modified) species and relative fresh weight in mixture. Because roots of different species / genotypes, size, or viability (by age or stress) produce variable amounts of (extractable) DNA independent of biomass, the estimation of relative root abundance can be biased (Mommer et al. 2008; Fisk et al. 2010; Haling et al. 2011). For example, Riley et al. (2010) found higher DNA amounts in young roots, suggesting that DNA assays reflect root function rather than root dry weight. To determine more exact root biomasses from amounts of absolute root DNA, additional calibration is required by quantifying root mass after "traditional" root rinsing (Haling et al. 2011). Mommer et al. (2008) suggested using relative DNA abundances rather than absolute concentration readings. This also requires an accurate (multi-)species reference series similar to the calibration of quantitative IR spectroscopy (see above); however, under the assumption that the DNA of each species in a sample is extracted with the same efficiency in root mixtures as in monoculture (i.e. reference) samples, the absence of a truly quantitative DNA extraction is no longer a problem. If additional internal standards are used to account for the variability between DNA extraction methods and DNA quality after storage (i.e. refrigerated, dried, etc.), the quantification of root proportions with qPCR methods is envisioned to become a standard method, replacing manual sorting approaches especially in low diversity or well-known ecosystems which allow for the establishment of sufficient calibration curves.

To date, DNA is most commonly extracted from rinsed root systems; while the subsampling of root segments can lead to an underestimation of species richness if not enough root fragments are sampled, rinsing of soil samples causes the potential loss of root segments, especially of thin, less sturdy roots. Riley et al. (2010) developed a method to quantify roots of various grasses, legumes and some forbs directly from soil using qPCR with species-specific TaqMan ${ }^{\circledR}$ probes designed across the ITS region, avoiding possible loss of (fine) root material by the rinsing process. For lyophilised roots of two Lolium spp., close correlations $\left(R^{2}=0.99\right)$ were found between root biomass and DNA amounts at low root densities ex situ (up to $1.6 \mathrm{~g}$ roots kg soil ${ }^{-1}$ ). DNA of dead roots was found to degrade within days, but seed banks were found to lead to DNA detection in the absence of living roots (Riley et al. 2010). Thus, in the case of DNA extraction from soil, the background DNA concentration, as well as the influence of soil type on DNA extraction, 


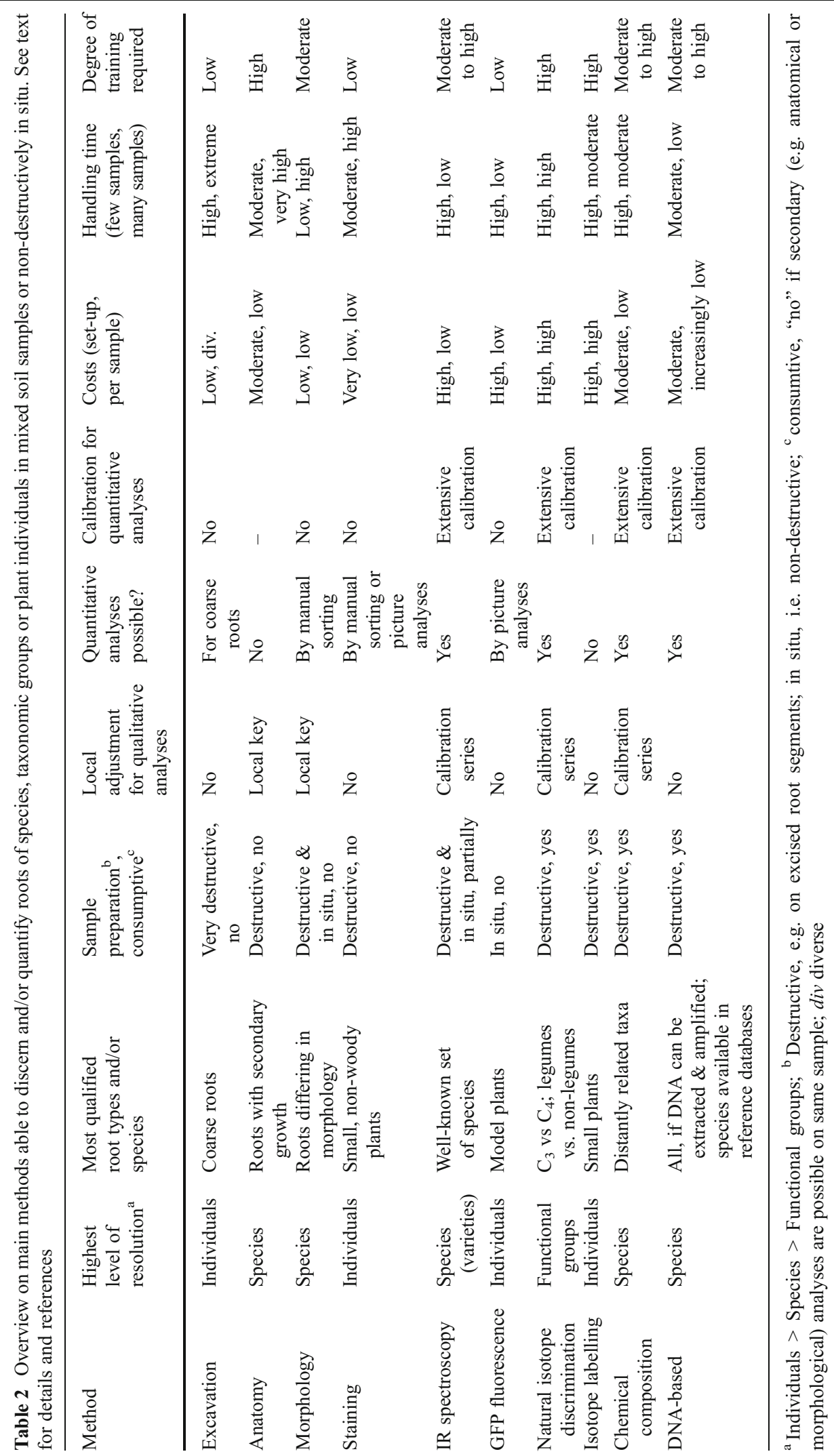


needs to be determined in addition to the abovementioned calibration series (Haling et al. 2011).

In summary, DNA-based approaches provide valuable tools for species identification and quantification as results obtained with molecular techniques are not dependent on the environment or the trained eye of the researcher. Multi-loci DNA barcoding approaches are the most promising techniques to date for species identification in diverse ecosystems. However, uncertainties still remain in respect of false positives or missing species; hence, until DNA barcode libraries are available for a broad range of species, many molecular techniques may be more applicable to studies where a rather small number of species will be examined. Quantification of root proportions or root biomass by $\mathrm{qPCR}$ will replace manual root sorting in ecosystems with limited amounts of species, allowing for extensive calibration series on monocultures and artificial root mixtures.

\section{Conclusion}

The available techniques for determining root species identity differ broadly in their applicability to distinguish and to quantify the root systems of functional groups, plant taxa and individual plants (Table 2). Because many root traits may vary with environmental parameters, it seems likely that the search for the "holy grail" of an anatomy, morphology or secondary compound-based root system taxonomy will remain unsuccessful. IR spectroscopy is the most promising method for non-destructive root species identification and quantification, in combination with (mini-)rhizotron analyses, in the future. Among the destructive approaches, multi-loci "barcode" sequencing is the most promising technique to determine species identities, especially after reference libraries become broadly available, and qPCR approaches will ease root quantification in ecosystems which allow for the establishment of extensive reference curves. The increasing interest in belowground research is envisioned to bring these techniques from niche existence to broad application. However, "classical" determination criteria, such as exodermis morphology, will remain important for now because they are not consumptive and allow for "secondary" analyses (e.g., determination of root branching structure, specific root area, anatomy, etc.) of the same segment. Further efforts are needed to facilitate the use and the development of fast and reliable methods and to standardize protocols and key criteria to enable easy comparisons between studies.

Acknowledgement The authors wish to thank two anonymous reviewers for valuable comments on an earlier version of the manuscript. B.R. acknowledges support by a postdoctoral fellowship awarded by the Jacob Blaustein Center for Scientific Cooperation (BCSC), Israel.

Open Access This article is distributed under the terms of the Creative Commons Attribution License which permits any use, distribution, and reproduction in any medium, provided the original author(s) and the source are credited.

\section{References}

Agerer R (1988) Colour atlas of ectomycorrhizae. Einhorn Verlag, Schwäbisch Gemünd

Ali HAM, Mayes RW, Hector BL, Verma AK, Orskov ER (2005) The possible use of $n$-alkanes, long-chain fatty alcohols and long-chain fatty acids as markers in studies of the botanical composition of the diet of free-ranging herbivores. J Agr Sci 143:85-95

Baldwin JP, Tinker PB (1972) Method for estimating lengths and spatial patterns of two interpenetrating root systems. Plant Soil 37:209-213

Barber SA (1995) Soil nutrient bioavailability: a mechanistic approach. Wiley, New York

Basconsuelo S, Grossoa M, Molina MG, Malpassia R, Kraus T, Bianco C (2011) Comparative root anatomy of papilionoid legumes. Flora 206:799-807

Bobowski BR, Hole D, Wolf PG, Bryant L (1999) Identification of roots of woody species using polymerase chain reaction (PCR) and restriction fragment length polymorphism (RFLP) analysis. Mol Ecol 8:485-491

Böhm W (1979) Methods of studying root systems. Springer, Berlin

Bookman PA, Mack RN (1982) Root interaction between Bromus tectorum and Poa pratensis: a three-dimensional analysis. Ecology 63:640-646

Brisson J, Reynolds JF (1994) The effect of neighbors on root distribution in a creosotebush (Larrea tridentata) population. Ecol 75:1693-1702

Brundrett MC, Kendrick B (1988) The mycorrhizal status, root anatomy, and phenology of plants in a Sugar maple forest. Can J For Res 66:1153-1173

Brunner I, Brodbeck S, Buchler U, Sperisen C (2001) Molecular identification of fine roots of trees from the Alps: reliable and fast DNA extraction and PCR-RFLP analyses of plastid DNA. Mol Ecol 10:2079-2087

Button J, Vardi A, Spiegel-Roy P (1976) Root peroxidase isoenzymes as an aid in Citrus breeding and taxonomy. Theor Appl Genet 47:119-123

Cahill JF, McNickle GG, Haag JJ, Lamb EG, Nyanumba SM, St. Clair CC (2010) Plants integrate information about nutrients and neighbors. Science 328:1657 
Caldwell MM, Richards JH, Manwaring JH, Eissenstat DM (1987) Rapid shifts in phosphate acquisition show direct competition between neighbouring plants. Nature 327:615-616

Caldwell MM, Manwaring JH, Durham SL (1991) The microscale distribution of neighboring plant-roots in fertile soil microsites. Funct Ecol 5:765-772

CBOL Plant Working Group (2009) A DNA barcode for land plants. PNAS 106:12794-12797

Chalmers JM, Griffiths PR (2002) Handbook of vibrational spectroscopy. Wiley, Chichester

Clarke FC, Hammond SV, Jee RD, Moffat AC (2002) Determination of the information depth and sample size for the analysis of pharmaceutical materials using reflectance near-infrared microscopy. Appl Spectrosc 56:1475-1483

Coleman SW, Barton FE, Meyer RD (1985) The use of near infrared reflectance spectroscopy to predict species composition of forage mixtures. Crop Sci 25:834-837

Corre-Hellou G, Crozat Y (2005) Assessment of root system dynamics of species grown in mixtures under field conditions using herbicide injection and ${ }^{15} \mathrm{~N}$ natural abundance methods: a case study with pea, barley and mustard. Plant Soil 276:177-192

Cutler DF, Rudall PJ, Gasson PE, Gale RMO (1987) Root identification manual of trees and shrubs. A guide to the anatomy of roots of trees and shrubs hardy in Britain and northern Europe. Chapman and Hall, London

Dawson LA, Mayes RW, Elston DA, Smart TS (2000) Root hydrocarbons as potential markers for determining species composition. Plant Cell Environ 23:743-750

de Kroon H, Mommer L, Nishiwaki A (2003) Root competition: towards a mechanistic understanding. In: de Kroon $\mathrm{H}$, Visser EJW (eds) Root ecology. Springer, Berlin, pp 215235

Donaldson DE, Robinson TW (1971) Fluorescent dyes, their uptake and translocation in plants. Water Resour Res 7:692-696

Dove H, Bolger TP (2005) The potential for using the alkanes and long-chain alcohols of plant cuticular wax to distinguish the contribution of different plant species to a mixed root mass. In: O’Mara FP, Wilkins RJ, Mannetje L, Lovett DK, Rogers PAM, Boland TM (eds) The XX international grassland congress: offered papers. Academic Publishers, Wageningen, pp 646-647

Dove H, Mayes RW, Freer M (1996) Effects of species, plant part, and plant age on the n-alkane concentrations in the cuticular wax of pasture plants. Aust J Agr Res 47:13331347

Dyer D, Brown DA (1983) Relationship of fluorescent intensity to ion uptake and elongation rates of soybean roots. Plant Soil 72:127-134

El Zemrany H, Czarnes S, Hallett PD, Alamercery S, Bally R, Jocteur Monrozier L (2007) Early changes in root characteristics of maize (Zea mays) following seed inoculation with the PGPR Azospirillum lipoferum CRT1. Plant Soil 291:109-118

Eleki K, Cruse RM, Albrecht KA (2005) Root segregation of $\mathrm{C}_{3}$ and $\mathrm{C}_{4}$ species using carbon isotope composition. Crop Sci 45:879-882

Eshel A, Beeckman T (2012) Plant roots: the hidden half, 4th edn. CRC Press, New York
Faget M, Herrera JM, Stamp P, Aulinger-Leipner I, Frossard E, Liedgens M (2009) The use of green fluorescent protein as a tool to identify roots in mixed plant stands. Funct Plant Biol 36:930-937

Faget M, Liedgens M, Stamp P, Flütsch P, Herrera JM (2010) A minirhizotron imaging system to identify roots expressing the green fluorescent protein. Comput Electron Agr 74:163-167

Farquhar GD, Ehleringer JR, Hubick KT (1989) Carbon isotope discrimination and photosynthesis. Annu Rev Plant Physiol Plant Mol Biol 40:503-537

Finér L, Messier C, De Grandpré L (1997) Fine-root dynamics in mixed boreal conifer - broad-leafed forest stands at different successional stages after fire. Can J For Res 27:304-314

Fisk MC, Yanai RD, Fierer N (2010) A molecular approach to quantify root community composition in a northern hardwood forest - testing effects of root species, relative abundance, and diameter. Can J For Res 40:836-841

Foley WJ, Mcllwee A, Lawler I, Aragones L, Woolnough AP, Berding N (1998) Ecological applications of near infrared reflectance spectroscopy - a tool for rapid, cost-effective prediction of the composition of plant and animal tissues and aspects of animal performance. Oecologia 116:293305

Frank DA, Pontes AW, Maine EM, Caruana J, Raina R, Raina S, Fridley JD (2010) Grassland root communities: species distributions and how they are linked to aboveground abundance. Ecology 91:3201-3209

Fußeder A (1986) Verteilung der Wurzelsysteme von Zea mays L. und Lupinus luteus L. in Mischkultur im Hinblick auf die Konkurrenz um Phosphat und Kalium. Z Pflanz Bodenkunde 149:541-547

Gamalero E, Trotta A, Massa N, Copetta A, Martinotti MG, Berta G (2004) Impact of two fluorescent pseudomonads and an arbuscular mycorrhizal fungus on tomato plant growth, root architecture and $\mathrm{P}$ acquisition. Mycorrhiza 14:185-192

Gealy DR, Fischer AJ (2010) 13C discrimination: a stable isotope method to quantify root interactions between $\mathrm{C}_{3}$ rice (Oryza sativa) and $\mathrm{C}_{4}$ barnyardgrass (Echinochloa crus-galli) in flooded fields. Weed Sci 58:359-368

Goodwin RH, Kavanagh F (1948) Fluorescing substances in roots. Bull Torrey Bot Club 75:1-17

Günzler H, Gremlich HU (2002) IR spectroscopy - an introduction. Wiley-VCH, Weinheim

Haling R, Simpson R, McKay A, Hartley D, Lambers H, OphelKeller K, Wiebkin S, Herdina H, Riley I, Richardson A (2011) Direct measurement of roots in soil for single and mixed species using a quantitative DNA-based method. Plant Soil 348:123-137

Hegnauer R, Hegnauer M (2001) Chemotaxonomie der Pflanzen XIb-2 - Leguminosae: Teil 3. Birkhäuser, Basel

Hölscher D, Hertel D, Leuschner C, Hottkowitz M (2002) Tree species diversity and soil patchiness in a temperate broadleaved forest with limited rooting space. Flora 197:118-125

Holzapfel C, Alpert P (2003) Root cooperation in a clonal plant: connected strawberries segregate roots. Oecologia 134:72-77

Hsu SCP (1997) Infrared spectroscopy. In: Settler FA (ed) Handbook of instrumental techniques for analytical chemistry. Prentice-Hall, New Jersey, pp 247-283 
Huang B, Fry JD (1998) Root anatomical, physiological, and morphological responses to drought stress for tall fescue cultivars. Crop Sci 38:1017-1022

Huber-Sannwald E, Pyke DA, Caldwell MM, Durham S (1998) Effects of nutrient patches and root systems on the clonal plasticity of a rhizomatous grass. Ecol 79:2267-2280

Hudson ME (2008) Sequencing breakthroughs for genomic ecology and evolutionary biology. Mol Ecol Res 8:3-17

Jackson RB, Moore LA, Hoffmann WA, Pockman WT, Linder CR (1999) Ecosystem rooting depth determined with caves and DNA. PNAS 96:11387-11392

Jones FA, Erickson DL, Bernal MA, Bermingham E, Kress WJ, Herre EA, Muller-Landau HC, Turner BL (2011) The roots of diversity: below ground species richness and rooting distributions in a tropical forest revealed by DNA barcodes and inverse modeling. PLoS One 6:e24506

Kesanakurti PR, Fazekas AJ, Burgess KS, Percy DM, Newmaster SG, Graham SW, Barrett SCH, Hajibabaei M, Husband BC (2011) Spatial patterns of plant diversity below-ground as revealed by DNA barcoding. Mol Ecol 20:1289-1302

Kim SW, Ban SH, Chung H, Cho S, Chung HJ, Choi PS, Yoo OJ, Liu JR (2004) Taxonomic discrimination of flowering plants by multivariate analysis of Fourier transform infrared spectroscopy data. Plant Cell Rep 23:246-250

Kloeppel BD, Gower ST, Treichel IW, Kharuk S (1998) Foliar carbon isotope discrimination in Larix species and sympatric evergreen conifers: a global comparison. Oecologia 114:153-159

Kress WJ, Erickson DL, Jones FA, Swenson NG, Perez R, Sanjur O, Bermingham E (2009) Plant DNA barcodes and a community phylogeny of a tropical forest dynamics plot in Panama. PNAS 106:18621-18626

Lafitte HR, Champoux MC, McLaren G, O’Toole JC (2001) Rice root morphological traits are related to isozyme group and adaptation. Field Crop Res 71:57-70

Lei P, Bauhus J (2010) Use of near-infrared reflectance spectroscopy to predict species composition in tree fine-root mixtures. Plant Soil 333:93-103

Leva PE, Aguiar MR, Oesterheld M (2009) Underground ecology in a Patagonian steppe: root traits permit identification of graminoid species and classification into functional types. $\mathrm{J}$ Arid Environ 73:428-434

Li L, Sun JH, Zhang FS, Guo TW, Bao XG, Smith FA, Smith SE (2006) Root distribution and interactions between intercropped species. Oecologia 147:280-290

Linder CR, Moore LA, Jackson RB (2000) A universal molecular method for identifying underground plant parts to species. Mol Ecol 9:1549-1559

Litav M, Harper JL (1967) A method for studying spatial relationships between the root systems of two neighbouring plants. Plant Soil 26:389-392

Lopez-Zamora I, Comerford NB, Muchovej RM (2004) Root development and competitive ability of the invasive species Melaleuca quinquenervia (Cav.) S.T. Blake in the South Florida flatwoods. Plant Soil 263:239-247

Ludlow MM, Troughton JH, Jones RJ (1976) A technique for determining the proportion of $\mathrm{C}_{3}$ and $\mathrm{C}_{4}$ species in plant samples using stable natural isotope's of carbon. J Agr Sci 87:625-632

McNickle GG, Cahill JF, Deyholos M (2008) A PCR-based method for the identification of the roots of $10 \mathrm{co}-$ occurring grassland species in mesocosm experiments. Botany 86:485-490

Meinen C (2008) Fine root dynamics in broad-leaved deciduous forest stands differing in tree species diversity. Dissertation, University of Göttingen, Germany

Meinen C, Hertel D, Leuschner C (2009a) Biomass and morphology of fine roots in temperate broad-leaved forests differing in tree species diversity: is there evidence of below-ground overyielding? Oecologia 161:99-111

Meinen C, Hertel D, Leuschner C (2009b) Root growth and recovery in temperate broad-leaved forest stands differing in tree species diversity. Ecosystems 12:1103-1116

Mommer L, Wagemaker CAM, de Kroon H, Ouborg NJ (2008) Unravelling below-ground plant distributions: a real-time polymerase chain reaction method for quantifying species proportions in mixed root samples. Mol Ecol Res 8:947-953

Moore LA, Field CB (2005) A technique for identifying the roots of different species in mixed samples using nuclear ribosomal DNA. J Veg Sci 16:131-134

Murakami T, Shimano S, Kaneda S, Nakajima M, Urashima Y, Miyoshi N (2006) Multicolor staining of root systems in pot culture. Soil Sci Plant Nutr 52:618-622

Murphy MT, McKinley A, Moore TR (2009) Variations in aboveand below-ground vascular plant biomass and water table on a temperate ombrotrophic peatland. Botany 87:845-853

Nakaji T, Noguchi K, Oguma H (2008) Classification of rhizosphere components using visible-near infrared spectral images. Plant Soil 310:245-261

Naumann A, Heine G, Rauber R (2010) Efficient discrimination of oat and pea roots by cluster analysis of Fourier transform infrared (FT IR) spectra. Field Crop Res 119:78-84

Nordby HE, Nagy S (1981) Chemotaxonomic study of neutral coumarins in roots of Citrus and Poncirus by thin-layer, gas-liquid and high-performance liquid chromatographic analyses. J Chromatogr A 207:21-28

Pierret A (2008) Multi-spectral imaging of rhizobox systems: new perspectives for the observation and discrimination of rhizosphere components. Plant Soil 310:263-268

Polley HW, Johnson HB, Mayeux HS (1992) Determination of root biomasses of three species grown in a mixture: using stable isotopes of carbon and nitrogen. Plant Soil 142:97-106

Prakash N (1972) Root-wood anatomy of some tropical economic plants. Notes Jodrell Laboratory. Royal Bot Gardens Kew 7:1-19

Rewald B, Ephrath JE (2012) Minirhizotron technique. In: Eshel A, Beeckman T (eds) Plant roots: the hidden half, 4th edn. CRC Press, New York

Rewald B, Leuschner C (2009) Belowground competition in a broad-leaved temperate mixed forest: pattern analysis and experiments in a four-species stand. Eur J For Res 128:387-398

Rewald B, Leuschner C, Wiesman Z, Ephrath JE (2011) Influence of salinity on root hydraulic properties of three olive varieties. Plant Biosys 145:12-22

Reynolds HL, Packer A, Bever JD, Clay K (2003) Grassroots ecology: plant-microbe-soil interactions as drivers of plant community structure and dynamics. Ecology 84:22812291

Rice KJ, Gordon DR, Hardison JL, Welker JM (1993) Phenotypic variation in seedlings of a keystone tree species (Quercus douglasii) - the interactive effects of acorn source and competitive environment. Oecologia 96:537-547 
Ridgway KP, Duck JM, Young JPW (2003) Identification of roots from grass swards using PCR-RFLP and FFLP of the plastid trnL (UAA) intron. BMC Ecol 3:8

Riedel H (1937) Bau und Leistungen des Wurzelholzes. Gebrüder Borntraeger, Leipzig

Riley IT, Wiebkin S, Hartley D, McKay AC (2010) Quantification of roots and seeds in soil with real-time PCR. Plant Soil 331:151-163

Roumet C, Picon-Cochard C, Dawson LA, Joffre R, Mayes R, Blanchard A, Brewer MJ (2006) Quantifying species composition in root mixtures using two methods: near-infrared reflectance spectroscopy and plant wax markers. New Phytol 170:631-638

Rumbaugh MD, Clark DH, Pendery BM (1988) Determination of root mass ratios in alfalfa-grass mixtures using near infrared reflectance spectroscopy. J Range Manage 41:488-490

Schenk HJ (2006) Root competition: beyond resource depletion. J Ecology 94:725-739

Schenk HJ, Callaway RM, Mahall BE (1999) Spatial root segregation: are plants territorial? Adv Ecol Res 28:145-180

Schmidt S, Stewart GR (2003) $\delta^{15} \mathrm{~N}$ values of tropical savanna and monsoon forest species reflect root specialisations and soil nitrogen status. Oecologia 134:569-577

Seneviratne GI, Harborne JB (1992) Constitutive flavonoids and induced isoflavonoids as taxonomic markers in the genus Vigna. Biochemic Syst Ecol 20:459-467

Sharma A, Schulman SG (1999) Introduction to fluorescence spectroscopy. Wiley, New York

Shearer G, Kohl DH, Virginia RA, Bryan BA, Skeeters JL, Nilsen ET, Sharifi MR, Rundel PW (1983) Estimates of $\mathrm{N}_{2}$-fixation from variation in the natural abundance of ${ }^{15} \mathrm{~N}$ in Sonoran Desert ecosystems. Oecologia 56:365373

Shenk JS, Westerhaus MO, Hoover MR (1979) Analysis of forages by infrared reflectance. J Dairy Sci 62:807-812

Skrabal PM (2009) Spektroskopie. Eine methodenübergreifende Darstellung vom UV- bis zum NMR-Bereich. UTB, Zurich, Switzerland

Soussana JF, Teyssonneyre F, Picon-Cochard C, Dawson L (2005) A trade-off between nitrogen uptake and use increases responsiveness to elevated $\mathrm{CO}_{2}$ in infrequently cut mixed $\mathrm{C}_{3}$ grasses. New Phytol 166:217-230

Svejcar TJ, Boutton TW (1985) The use of stable carbon isotope analysis in rooting studies. Oecologia 67:205-208
Taggart JM, Cahill JF, McNickle GG, Hall JC (2011) Molecular identification of roots from a grassland community using size differences in fluorescently labelled PCR amplicons of three $c p$ DNA regions. Mol Ecol Res 11:185-195

Taylor JH, Waltenbaugh A, Shields M (2008) Impact of vesicular arbuscular mycorrhiza on root anatomy in Zea mays and Lycopersicon esculentum. African J Agr Res 3:1-6

Tosti G, Thorup-Kristensen K (2010) Using coloured roots to study root interaction and competition in intercropped legumes and non-legumes. J Plant Ecol 3:191-199

Trockenbrodt M, Richter HG, Möller-Lindenhof Y, Dujesiefken D (2001) Identifizierung von Baumwurzeln - Möglichkeiten der Bestimmung anhand der Holz und Rindenstruktur. Stadt und Grün 6:430-434

Van Wyk BE, Yenesew A, Dagne E (1995) Chemotaxonomic significance of anthraquinones in the roots of Asphodeloideae (Asphodelaceae). Biochem Syst Ecol 23:277-281

Vandenkoornhuyse P, Ridgway KP, Watson IJ, Fitter AH, Young JPW (2003) Co-existing grass species have distinctive arbuscular mycorrhizal communities. Mol Ecol 12:3085-3095

Walker MA, Liu L (1995) The use of isozymes to identify 60 grapevine rootstocks (Vitis spp.). Am J Enol Viticult 46:299-305

Wang X, Qin M, Liang Z (2003) Microscopical identification of roots and rhizome of six species of plants from Viola in the region of Nanjing. Zhong Yao Cai 26:401-403, In Chinese, English abstract

Wardle DA, Peltzer DA (2003) Interspecific interactions and biomass allocation among grassland plant species. Oikos 100:497-506

Williams DG, Ehleringer JR (2000) Carbon isotope discrimination and water relations of oak hybrid populations in southwestern Utah. West N Am Naturalist 60:121-129

Wong SC, Osmond CB (1991) Elevated atmospheric partialpressure of $\mathrm{CO}_{2}$ and plant growth. 3. Interactions between Triticum aestivum $\left(\mathrm{C}_{3}\right)$ and Echinochloa frumentacea $\left(\mathrm{C}_{4}\right)$ during growth in mixed culture under different $\mathrm{CO}_{2}, \mathrm{~N}$ nutrition and irradiance treatments, with emphasis on belowground responses estimated using the $\delta^{13} \mathrm{C}$ value of root biomass. Aust J Plant Physiol 18:137-152

Yanai RD, Fisk MC, Fahey TJ, Cleavitt NL, Park BB (2008) Identifying roots of northern hardwood species: patterns with diameter and depth. Can J For Res 38:2862-2869

Zhao HR, Wang XY, Chen GH, Wen SM (2004) Identification of wheat varieties by FT IR spectrum. Spectrosc Spect Anal 24:1338-1341, In Chinese, English abstract 